\title{
Predicting Financial Distress and Financial Performance Using Political Connection
}

\author{
Ramly $^{1}$, Sitti Haerani ${ }^{2}$,Yohanes Rura ${ }^{3}$, Syarifuddin Rasyid ${ }^{4}$ \\ \{abdullah.ramly@yahoo.co.id ${ }^{1}$, haeranisiti68@yahoo.co.id², rurayohanis@gmail.com³ \\ syariefdin07@gmail.com $\left.{ }^{4}\right\}$ \\ Universitas Hasanuddin, Makassar, Indonesia ${ }^{1-4}$
}

\begin{abstract}
The purpose of this study is to investigate the relationship between financial performance and financial distress with political connections. This study examines (1) the relationship between political connections to financial distress (2) the relationship between political connections to financial performance. The research location is on the Indonesia Stock Exchange (IDX) using all secondary data in the property and real estate sector. Sampling was done purposively and produced 40 observational data for 2014-2017. Data analyzed using linear regression. The results showed a negative relationship between financial distress and political connections and, likewise, a negative result between financial performance and political connections.
\end{abstract}

Keywords: Financial performance, financial distress, political connection.

\section{Introduction}

The Jokowi-JK government policy, which focuses on infrastructure during his administration, is a phenomenon that has attracted investors' attention because of the policy direction that focuses on companies in the infrastructure, property, and real state sectors. Every policy issued by the government certainly has a political impact. A number of studies have found that political connections or political connections can improve company performance. According to [1] finding political connections helps companies to secure favorable regulatory conditions and access resources such as bank loans [2], [3], help increase asset returns [4], which in turn has an impact on increasing the value of the company [5]-[7] or improve their performance [8]. According to [9], Transitional countries are characterized by a number of institutional difficulties for private companies. These difficulties impose high costs on private companies and ultimately damage their performance. Connections or political status help reduce these costs and thus improve company performance.

Other research on an international level shows that politically connected companies show operational results that are not in line with expectations. [4] obtained research results that companies that have political connections have implications for the low profitability for three years after privatization. The same thing was found [10] that politically bound companies show lower returns compared to their competitors. However, the presence of political connections seems to increase (low) performance; meanwhile, the cessation of political 
relations is accompanied by a decline in operational performance. [11] determined that after the death of a politician, the fluctuations in the income of companies located in his city were significantly reduced.

\section{Theoretical Framework and Hypothesis Development}

In grabbing hand theory, [12] have developed a bargaining model between politicians and company managers. Assuming that private ownership leads to the more efficient allocation of resources than politicians' control, in theory, it shows that private ownership is more favored by politicians because they can seek fees or take more resources from private shareholders using bribes or overwork. In this context, connections with politicians have the potential to corporate damage value. Therefore, the relationship of political connections to financial distress and financial performance is predicted to have a negative relationship.

\subsection{Hypothesis Development}

Companies that are connected with politicians are expected to avoid financial distress. This is because political links are considered able to strengthen the performance of corporate funding so as to avoid the financial distress situation. A company experiences financial conditions that are not good and results in and is in a situation of financial difficulties if the company is unable to realize its financial obligations by violating the terms or debt covenants (debt covenants) accompanied by the elimination or reduction of the distribution of dividends to shareholders [13]. This research focuses on the relationship between companies experiencing financial distress in the property and the real estate sector due to the fact that some companies experience distress even though there are still political connections in their corporate structure. This research predicts that the existence of political connections has a negative relationship with financial distress.

H1: Political connections negatively affect financial distress

A number of studies like [9] and [8] show significant positive results between financial performance and political connections. This happens in the context of companies that do not experience financial distress. This study differs from previous studies because it focuses on a sample of companies experiencing financial distress so that it is hypothesized as follows:

$\mathrm{H} 2$ : Political Connection has a negative effect on financial performance

\section{Research Methods}

The study was conducted at the Indonesia Stock Exchange using secondary data from 2014 to 2017 . Hypothesis testing is the aim of this study. The correlational relationship is a type of relationship in this study. The unit of analysis is the company level, namely companies engaged in property and real estate traded on the Indonesia Stock Exchange (IDX). The time horizon in this study is the time series. The variables in this study consisted of the dependent variable, independent variable, and control variable. Independent variables used are political connections, control variables are the size, and financial performance and financial distress are dependent variables.

All property and real estate companies listed on the Indonesia Stock Exchange (IDX) from 2014-2017 are the population in this study. The sample selection is made by a purposive 
sampling method where all financial reports are first calculated based on the Altman z score to find the company in the condition of distress. A total of 10 companies in the field of property and real estate are eligible to be used as samples in this study.

The data in this study were collected through a computer search on the Indonesia Stock Exchange (IDX) website. The financial statements of companies that have gone public through an audit process by an independent public accountant are secondary data. The financial statement data is collected directly from the Capital Market Reference Center at the Indonesia Stock Exchange Building (IDX). Data on the independent variables of political connections are traced through www.bloomberg.com, www.marketscreener.com, and www.wikipedia.com. Financial Distress and Financial Performance variable data were obtained from financial statements.

Multiple linear regression is testing the hypothesis in this study using SPSS17 software. The regression model in this study is shown in the following two-equation stages.

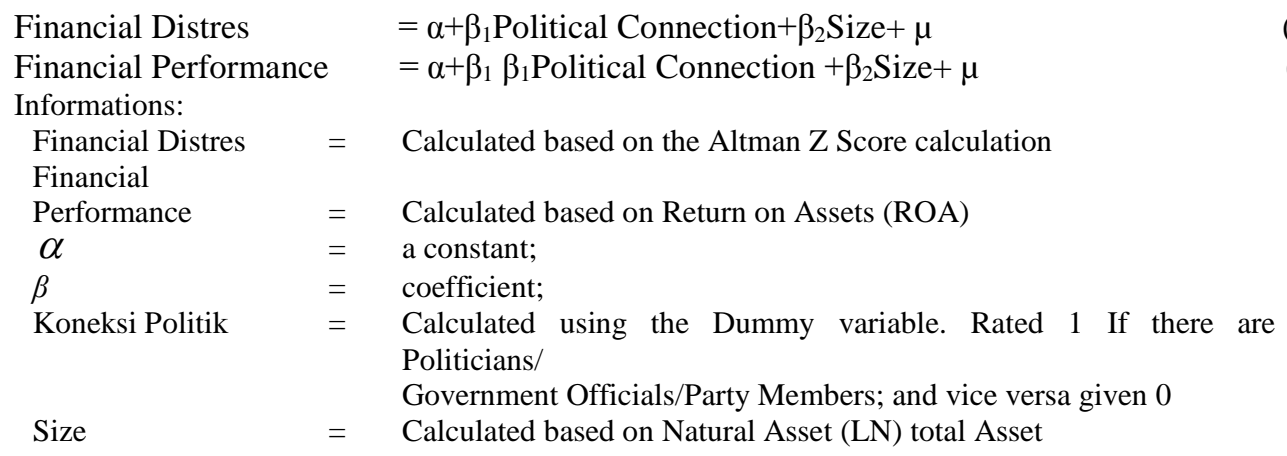

\section{Result}

Regression test results in the first equation show the $\mathrm{F}$ test results in table 1 at a significant level of $5 \%$, which means the first equation model should be used to predict Financial Distress.

Table 1. Test Model on Equation 1

\begin{tabular}{|c|c|c|c|c|c|c|}
\hline Model & & Sum of Squares & df & Mean Square & $\mathrm{F}$ & Sig. \\
\hline \multirow[t]{3}{*}{1} & Regression & 2.177 & 2 & 1.089 & 6.186 & $.005^{\mathrm{a}}$ \\
\hline & Residual & 6.511 & 37 & .176 & & \\
\hline & Total & 8.688 & 39 & & & \\
\hline
\end{tabular}

a. Predictors: (Constant), SIZE, POLITIK

b. Dependent Variable: DISTRES

Meanwhile, table 2 shows the political connection variable to financial distress that has a significant negative result at the alpha level of $5 \%$ and the magnitude of the coefficient of 0.374 and the control variable of the company size to financial distress also obtained a signi cant negative result at the alpha level of $5 \%$ with a coefficient of -0.088 . This result is in line with the hypothesis $(\mathrm{H} 1)$. 
Table 2. Hypothesis Test Equation 1

\begin{tabular}{|c|c|c|c|c|c|c|}
\hline & \multirow[b]{2}{*}{ Model } & \multicolumn{2}{|c|}{ Unstandardized Coefficients } & $\begin{array}{l}\text { Standardized } \\
\text { Coefficients }\end{array}$ & \multirow[b]{2}{*}{$\mathrm{t}$} & \multirow[b]{2}{*}{ Sig. } \\
\hline & & B & Std. Error & Beta & & \\
\hline \multirow[t]{3}{*}{1} & (Constant) & 3.838 & 1.270 & & 3.021 & .005 \\
\hline & POLITIK & -.374 & .143 & -.376 & -2.617 & .013 \\
\hline & SIZE & -.088 & .044 & -.285 & -1.988 & .054 \\
\hline
\end{tabular}

a. Dependent Variable: DISTRES

Regression results in the second equation show the results of the F test in table 3 obtain significance at the $5 \%$ level, which means the second equation model can be used to predict financial performance.

Table 3. Test Model on Equation 2

\begin{tabular}{llrrrrr}
\hline Model & & Sum of Squares & df & Mean Square & F & Sig. \\
\hline 1 & Regression & .019 & 2 & .010 & 6.006 & $.006^{\mathrm{a}}$ \\
& Residual & .059 & 37 & .002 & & \\
& Total & .078 & 39 & & & \\
\hline
\end{tabular}

a. Predictors: SIZE, POLITIK

b. Dependent: ROA

T-test results in table 4 show the political connection to the financial performance obtained significant negative results at the alpha level of $5 \%$ with a coefficient of -0.044 , and firm size control variables also obtained a significant positive result at the alpha level of $10 \%$ with a coefficient of 0.004 . These results are different from previous researchers. [9] obtain positive results while in research [4], [10], [11] get negative results. This difference is due to this research focusing on samples of companies that are predicted to experience financial distress so that the financial performance (ROA) obtained can be said to be unfavorable.

Table 4. Hypothesis Test Equation 2

\begin{tabular}{|c|c|c|c|c|c|c|}
\hline \multirow[b]{2}{*}{ Mode } & & \multicolumn{2}{|c|}{ Unstandardized Coefficients } & $\begin{array}{l}\text { Standardized } \\
\text { Coefficients }\end{array}$ & \multirow[b]{2}{*}{$\mathrm{t}$} & \multirow[b]{2}{*}{ Sig. } \\
\hline & & B & Std. Error & Beta & & \\
\hline \multirow[t]{3}{*}{1} & (Constant) & -.150 & .121 & & -1.241 & .222 \\
\hline & POLITIK & -.044 & .014 & -.463 & -3.213 & .003 \\
\hline & SIZE & .007 & .004 & .246 & 1.708 & .096 \\
\hline
\end{tabular}

a. Dependent Variable: ROA 


\section{Discussion}

Hypothesis testing results on the two regression models show that financial distress and financial performance have a negative relationship with political connections. This fact shows different results from research [9] and [8] that financial performance is positively related to political connections but in line with research [4], [10], [11]. Meanwhile, financial distress has negative results; this result is in line with expectations in this study because the samples collected are companies that are in a state of financial distress. If it is associated with the concept of political connections, companies that have political links are predicted to be able to improve the company's financial performance but viewed from the side of the company experiencing financial distress; there will be a decrease in financial performance.

\section{Conclusion}

Based on grabbing hand theory predicts a negative relationship between the presence of political connections between financial distress and financial performance due to the negative side of a politician such as hoping for a fee to be obtained and also the tendency of a politician to corrupt within a company. From the side of this theory, politicians tend to be self-interested so they tend to ignore the interests of companies. This then makes the company not optimal in terms of improving its performance and ultimately makes the company experience financial distress.

This research certainly gives information to every principle that the presence of political connections within the company is not profitable to benefit the company financially and tends to make the company in a state of financial distress.

\section{Reference}

[1] Agrawal. A and Knoeber. C. R..: Do Some Outside Directors Play a Political Role?," Ssrn (2000).

[2] Khwaja. A. I and Mian. A.: Do lenders favor politically connected firms? Rent provision in an emerging financial market. Q. J. Econ. vol. 120, no. 4, pp. 1371-1411 (2005).

[3] Faccio. M.: Politically connected firms. Am. Econ. Rev. vol. 96, no. 1, pp. 369-386 (2003).

[4] Boubakri. N, Cosset. J, and Saffar. W.: the Impact of Political Connections on Firms ' Operating. J. Financ. Res. vol. XXXV, no. 3, pp. 397-423 (2012).

[5] Roberts. B. E.: A Dead Senator Tells No Lies: Seniority and the Distribution of Federal Benefits. Midwest Polit. Sci. Assoc. vol. 34, no. 1, pp. 31-58 (1990).

[6] Fisman. R.: Estimating the Value of Political Connections. Am. Econ. Rev. vol. 91, pp. 153-164 (2001).

[7] Ramalho. R.: The Persistence of Corruption : Evidence from the 1992 Presidential Impeachment in Brazil. World Bank Work. Pap (2007).

[8] Johnson. S and Mitton. T.: Cronyism and capital controls: Evidence from Malaysia. J. financ. econ (2001).

[9] Li, L. Meng. H, Wang. Q, and Zhou. L.: Political connections, financing and firm performance : Evidence from Chinese private firms. J. Dev. Econ. vol. 87, pp. 283-299 (2008).

[10] Faccio. M.: Differences between Politically Connected and Nonconnected Firms: A CrossCountry Analysis. Financ. Manag. vol. 1, no. 2006, pp. 905-927 (2010).

[11] Faccio. M and Parsley. D. C.: Munich Personal RePEc Archive Sudden Deaths: Taking Stock of Geographic Ties Sudden Deaths: Taking Stock of Geographic Ties. Munich Pers. RePEc Arch., 
no. 6042 (2007).

[12] Shleifer. A and Vishny. R. W.: Politician and Firms. Q. J. Econ. vol. 106, pp. 461-488 (1994).

[13] Baldwin. C.: The Resolution of Claims in Financial Distress the Case of Massey Ferguson: Discussion. J. Finance. vol. 38, no. 2, p. 522 (1983). 